\title{
The avifauna of the Polylepis woodlands of the Andean highlands: the efficiency of basing conservation priorities on patterns of endemism
}

\author{
J. FJELDS
}

\begin{abstract}
Summary
The Andean páramo and puna zones may once have been densely dotted by woodlands, mainly of Polylepis, but human impact has now led to a highly disjunct distribution of this habitat. Because of the habitat fragmentation, many specialized woodland birds now show relictual distributions. Speciations to the Polylepis zone took place in Peru and Bolivia during cold/arid climatic periods, as Polylepis-dominated woodland refuges were isolated away from the humid cis-Andean zone and the pre-Andean scrub-forest in Bolivia. An efficient protection of biodiversity in a minimum of well-managed areas could be achieved, if efforts were concentrated in highlands near the proposed Pleistocene woodland refuges: $55 \%$ of all endemic and $67 \%$ of all threatened and near-threatened landbirds of the high Andean zone of Peru and Bolivia were recorded within three 10 $\times 10 \mathrm{~km}$ study plots near Cochabamba in Bolivia and east of Abancay and on the east slope of Cordillera Blanca in Peru. The biological basis for the efficiency of this approach is discussed.
\end{abstract}

Los páramos y punas Andinas pueden haber estado densamente poblados de bosques, principalmente de Polylepis, pero el impacto humano ha causado una distribución muy esparcida de este habitat. Debido a la fragmentación del habitat, muchos pájaros especializados al bosque, ahora muestran distribuciones rudimentales. La diferenciación de las especies en la zona de Polylepis se dió en Perú y Bolivia durante períodos climáticos fríos/aridos, al igual que los refúgios de bosques dominados por Polylepis fueron aislados de la zona húmeda cis-Andina y de la zone chaqueña en Bolivia. Se podría lograr una protección eficiente de la biodiversidad en un mínimo de áreas bien manejadas, si se concentrasen los esfuerzos en las sierras cerca de los refúgios propuestos de bosque Pleistocenico. Así es, que un $55 \%$ de los pájaros endémicos y $67 \%$ de todos los especies en peligro de extinción de la zona alto-Andina de Perú y Bolivia fueron registrados dentro de tres áreas de estudio de $10 \times 10 \mathrm{~km}$, cerca de Cochabamba en Bolivia, y al sureste de Abancay y en la vertiente oriental de la Cordillera Blanca en Perú. El artículo diserta los processos básicos.

\section{Introduction}

The páramo and puna zones at 3,500-4,500 $\mathrm{m}$ altitude in the Andes of South America are dominated by monotonous bunch-grass steppes and semi-desert. Locally, these habitats are broken by tiny woodland patches, which thus grow 
well above the upper fringe of the montane cloud-forests ("ceja de montaña"). The high-altitude woodlands comprise mainly trees and bushes of the genus Polylepis (Rosaceae), which are usually small and gnarled, but occasionally reach 15-20 $\mathrm{m}$ tall. These evergreen trees are well adapted to grow in places with regular night frost, in certain highlands nearly to 5,000 $\mathrm{m}$. In favourable places Polylepis will form mixed stands with Gynoxys, Buddleja, Escallonia and Weinmannia trees.

Many Polylepis woodlands "hang" on the upper parts of steep slopes, on boulder-scree or rocky outcrops, or form strips along streams. Botanists have attempted to give microclimatic explanations of this (see Simpson 1979), but Ellenberg (1958) instead suggested that these woodlands are the relicts of a once-widespread habitat. Recent studies (Jordan 1983, Fjeldså 1987 and unpublished, Kessler and Driesch unpublished) suggest wide ecological amplitudes for certain Polylepis species, which thus appear to be able to grow widely on ordinary compact soils, along the edges of the high plateaus, and also in some areas inside the puna. A main reason for the restriction of Polylepis in many districts to stream ravines and steep and rocky terrain seems to be that these places offer some protection against grassland fires and grazing. Laegaard (1992) concludes that some and maybe all grass páramo is secondary vegetation created and maintained by man's use of fire.

The direct evidence on the distribution of high-altitude Andean woodlands since the last Pleistocene glaciation is limited and conflicting, but the combined evidence indicates that man-made fires had a strong impact immediately after the Pleistocene, and which accelerated when the management of pastures for domesticated camelids started 7,500-4,500 BP (Wing 1986). Famines following over-exploitation of the highlands possibly paved the way for the Andean high cultures (Wari, Tiahuanuco, Inca), in which land use became technically advanced with a strict resource management (Earls 1991). However, the Spanish Conquista caused a breakdown of such traditions. Introductions of unfortunate agricultural practices, such as ploughing downhill with European-type ploughs, increased use of fire and a shift from camelids to sheep, has now led to severe land degradation (Ansión 1986).

Despite the nearly complete destruction of virgin high-altitude wood- and bushland habitat, many bird species survive in the tiny patches that remain (Fjeldså 1988). The Polylepis woodlands are favourable feeding habitats for birds because of the thick, rough and laminated bark, small leaves and in many woodlands also large amounts of vines and mistletoes and diverse shrubby undergrowth. In view of the strong pressure on these remnant habitats, surveys of their biota are strongly needed, together with analysis of how to identify top priority sites for conservation.

This paper presents results of a detailed study of the avifauna of relict highaltitude woodlands in Peru and Bolivia. The biogeographic patterns and diversification have been analysed by Fjeldså (1992), and the present paper reviews the biological basis for the efficiency of basing conservation priorities on local aggregations of endemic species rather than species richness. 


\section{Materials and methods}

Ornithological data were gathered from 1983 to 1991 at more than 400 sites above $3,500 \mathrm{~m}$ in Ecuador, Peru and Bolivia, mainly by myself and N. Krabbe (e.g. Fjeldså 1987, Krabbe 1991, Fjeldså and Maijer unpublished), with additional surveys by Frimer and Nielsen (1989). The results of these surveys were supplemented with published bird lists (especially Vuilleumier and Simberloff 1982) and with collecting data for the majority of museum specimens of birds from the relevant altitudinal zone in the Andes (see Fjeldsa and Krabbe 1990: 12-13 for a full review of institutions visited). The localities from which bird data are available are shown in Figure 1 together with important topographical features and names. Among the larger "gaps" in the coverage, those in southwestern Bolivia and the highland transition between Apurímac, Arequipa and Puno in Peru have monotonous habitats which are rather uninteresting in the present context. The paucity of records from the highlands fringing certain valleys in central Peru is more regrettable. These areas, which are hard to travel in because of difficult terrain and lack of roads, are marked with question marks on the review maps (Figure 4 ).

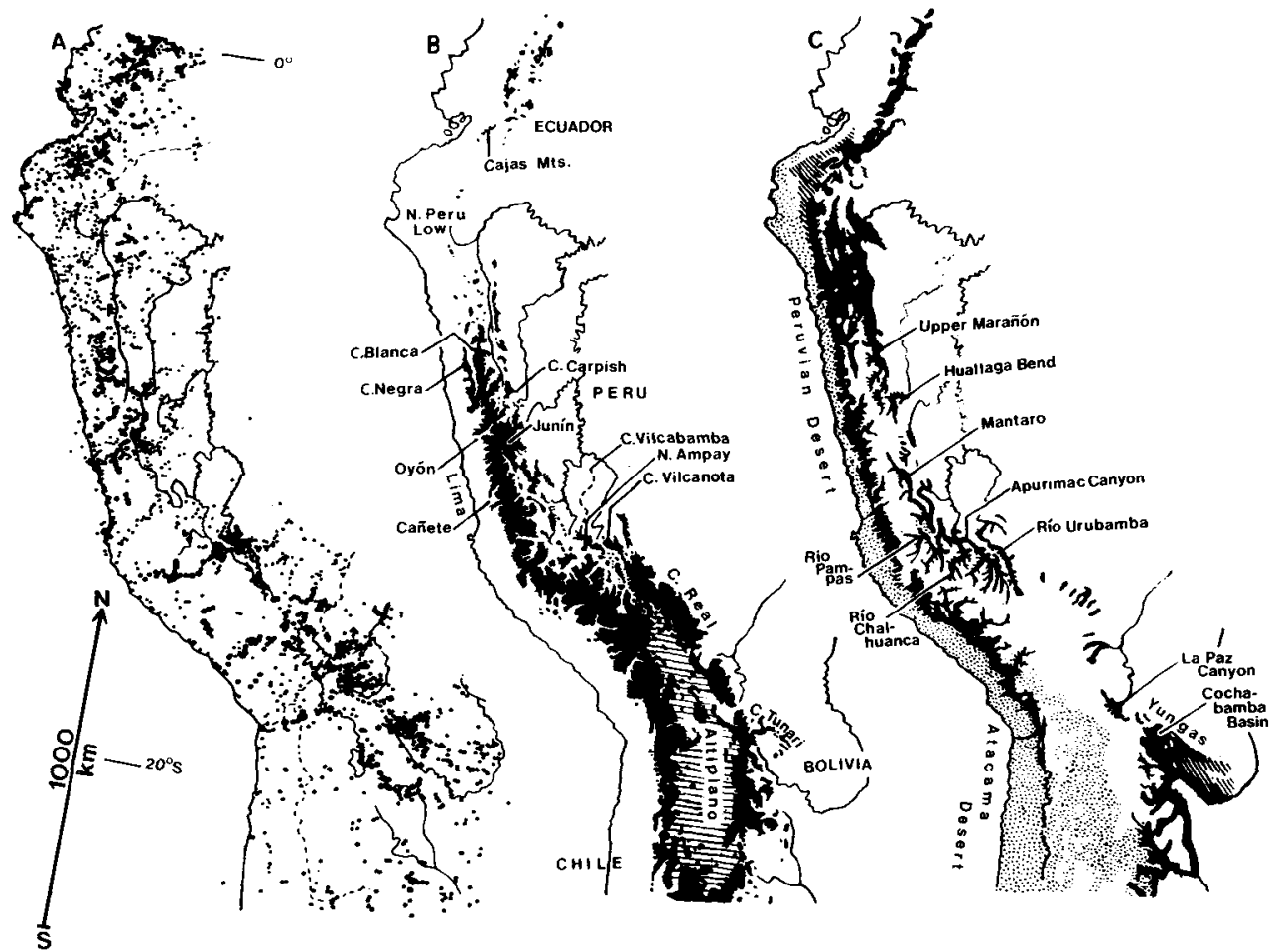

Figure 1. Ornithological collecting sites in the Andean zone from the equator to the southern border of Bolivia (A), with important topographic features and important geographical names (B and C). Black signature in $B$ marks areas above 4,000 $\mathrm{m}$ (the altiplano, which is a basin of inner drainage around $3,800 \mathrm{~m}$, shaded); black signature in $\mathrm{C}$ marks semi-arid valleys with bush-steppe, thorn-scrub and woodlands, hatching marks transitory vegetation towards lower-altitude deciduous woodland, and stippling marks deserts. 
Most open-land sites were visited for a few hours only and most woodland sites for 2-5 days, with a campsite within or close to a woodland. The main method was observing and listening for bird calls while stealing quietly through the terrain. This was supplemented with mist-netting, with 5-10 nets operated in most woodlands, and the nets moved every other day.

In order to evaluate the adequacy of my data, I usually recorded the birds in 10-minute periods spent within study plots of $c .100 \times 100 \mathrm{~m}$. In most woodlands, 2-3 plots with dense or complex vegetation were visited several times each, and some additional plots, selected for a broad coverage of microhabitats, were examined for 1-2 periods each. To illustrate the relationship between the effort and the number of species recorded, Figure 2 gives data from those six study sites where five plots had been surveyed for at least five 10-minute periods each, giving a total of four hours coverage. This record is compared with the total number of birds found by $2-4$ ornithologists during $3-4$ days in each of the woodlands.

Birds often missed by the four hours of sampling were tinamous, birds of prey, ground tyrants, and furnariids and emberizines of open country. These are typically widespread species which occur at low densities, but some of them

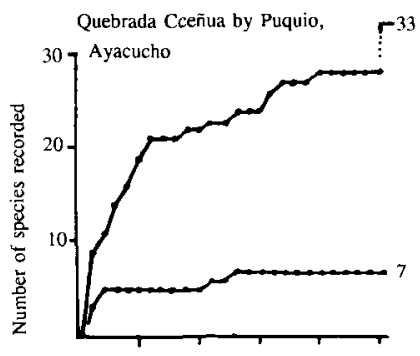

Cerro Quishuarrioc above Chuquibamba,

Cerro Palmaderas by Pampa Galeras,
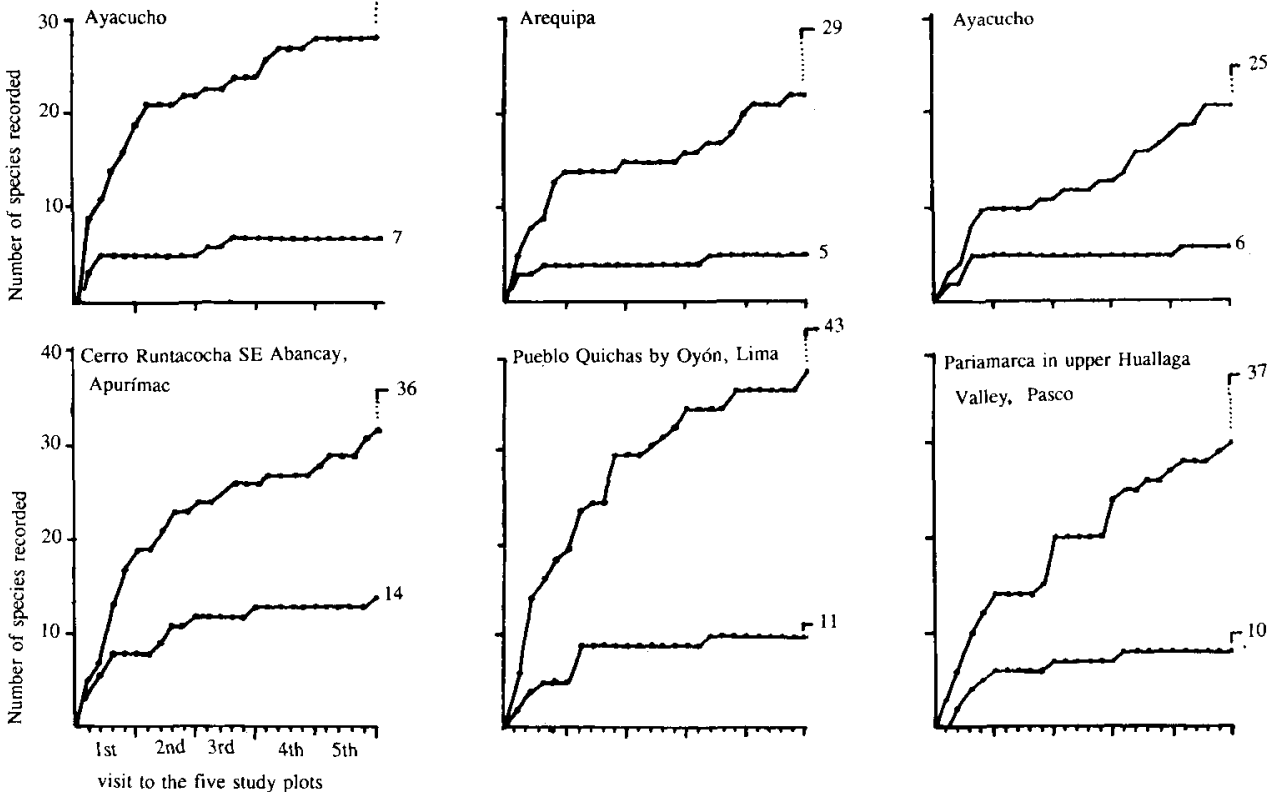

Figure 2. Number of bird species recorded in six Polylepis tracts in Peru, in relation to the number of ten-minute visits (with attentive watching and listening) to five onehectare plots covering various habitats within each woodland. The upper cumulative curve for each woodland shows the total number of species, the lower curve shows species of restricted geographical and habitat distribution (those mentioned for Figures 3 and ${ }_{4} \mathrm{~B}$ and $\mathrm{C}$ as well as Stripe-headed Antpitta, Giant Conebill and Thick-billed Siskin). The figures to the right of each diagram show the number of species recorded during 3-4 days in that area. 
are nomadic or opportunistic. Longer-lasting studies would certainly show a continued increase in the total number of species because of vagrancy, visits by birds from adjacent habitats and some faunal turnover.

The crucial question is how much this matters for the evaluation of the conservation importance of the individual localities. In order to judge this, separate curves were drawn in Figure 2 for species with restricted geographical or habitat distributions. These latter curves flatten out very rapidly, as half of the "good" species were found within the first half-hour. Comparisons with the total bird lists obtained in 3-4 days in each of the woodlands suggest that I overlooked Rusty-bellied Brush-finch Atlapetes nationi in the Pueblo Quichas sample, Bluemantled Thornbill Chalcostigma stanleyi and Andean Tit-spinetail Leptasthenura andicola in the Pariamarca sample. Data from other sites show that certain brushfinches Atlapetes and warbling-finches Poospiza sometimes avoid detection and that a single family of Giant Conebills Oreomanes fraseri moving between 2-4 adjacent Polylepis patches may sometimes go unnoticed for a day or two. The mist-netting rarely yielded species not recorded in other ways, the most usual exception being hummingbirds which may have been passing rapidly through the area.

Thus, while short-term studies are insufficient for recording the total number of species, they can be considered fairly adequate for the sedentary birds that are special for the patchy habitats. I conclude that localities visited for at least two days (that is, several times the observation effort presented in Figure 2) give a reliable review of the species worth conservation attention. This efficiency cannot be expected in the humid mid-altitude forests, since these have a less surveyable vegetation and many birds which customarily move over considerable areas as members of mixed feeding parties.

General habitat descriptions and comments on land use and possible human impact on the vegetation were made throughout the field surveys. More detailed descriptions of the topography and vegetation structure, and identification of dominant plant species, were made in all woodlands that were subject to closer study (especially by the botanist J. Brandbyge, during the 1987 expedition, and by $\mathrm{M}$. Kessler in 1991). The results of the field surveys were supplemented by examination of topographic maps, false-coloured satellite imagery of the entire highland of Peru (1: 250,00o, Mapa Planimétrico de Imágines de Satelite) and LANDSAT photos (one to three bands) of selected areas.

When drawing distribution maps for the biogeographic analysis (see Figure 3 for examples) it was assumed that each species inhabits areas with fairly uniform ecological conditions between adjacent records, unless it was unrecorded in suitable habitat in an intervening study site. Overall biogeographic patterns were studied by overlaying species distributions, using a $25 \times 25 \mathrm{~km}$ grid.

\section{Results}

The significance of Polylepis woodlands for birds

Well over 100 bird species occur regularly in Polylepis woodland (Table 1 in Fjeldså 1992). They include as many as 13 species currently regarded as threatened by extinction and seven regarded as near-threatened (Collar et al. 
1992; the threatened birds being Taczanowski's Tinamou Nothoprocta taczanowskii, Violet-throated Metaltail Metallura odomae, Royal Cinclodes Cinclodes (excelsior) aricomae, White-browed Tit-spinetail Leptasthenura xenothorax, Whitecheeked Cotinga Zaratornis (Ampelion) stresemanni, Ash-breasted Tit-tyrant Anairetes alpinus, White-tailed Shrike-tyrant Agriornis andicola, Tamarugo Conebill Conirostrum tamarugense, Rufous-bellied Saltator Saltator rufiventris, Cochabamba and Tucumán Mountain-finches Poospiza garleppi and P. baeri and Rufousbreasted and Plain-tailed Warbling-finches $P$. rubecula and $P$. alticola). However, there is a continuous range of specializations from opportunistic visitors (e.g. grassland birds which may roost in trees) to the 15-20 species which are specialists in woodlands above $c .3,500 \mathrm{~m}$ altitude, and it is mainly among these latter that the threatened species are found. The specialists include the scansorial Giant Conebill and White-browed Tit-spinetail, which feed exclusively on branches and trunks of Polylepis, searching for insects and spiders by peeling the bark; Ash-breasted Tit-tyrant, which takes insects exclusively in dense Polylepis canopies; and Thick-billed Siskin Carduelis crassirostris, which depends strongly on flowers and seeds of Polylepis, at least in its breeding season. Another specialization is shown by the Blue-mantled Thornbill, Tit-like Dacnis Xenodacnis parina and Plain-tailed Warbling-finch, which glean sugary secretions and aphids from the underside of leaves of associated Gynoxys bushes.

While the birds of the grassland habitats usually move down into adjacent valleys in periods of snow, the Polylepis specialists remain within their habitat patches (Fjeldså 1991a). They appear to be quite unaffected by snow, although during the worst spells they move from their preferred haunts to the most sheltered recesses within their "habitat island". Certain Polylepis-adapted birds can be seen (straggling non-breeders) in rugged, rocky terrain with only a few tiny Polylepis bushes or shrubbery of Baccharis, Gynoxys, Miconia or Ribes. However, White-browed Tit-spinetail, Ash-breasted Tit-tyrant and Giant Conebill have hardly ever been seen away from Polylepis trees. Because of the generally low dispersal, the biogeography of the Polylepis birds can be expected to reflect the past history of their habitat to a considerable extent.

Geographical distributions of some representative examples of Polylepisadapted birds are shown in Figure 3. While most open-land birds of the high Andes are widespread (patchy distributions being characteristic only of the birds of the patchy páramo habitats in the northern parts of the Andes), the birds of the Polylepis woodlands have patchy or restricted distributions as a general rule. In Stripe-headed Antpitta, Giant Conebill and Thick-billed Siskin (Figure 3, left) the distribution reflects the insularity of the habitat well, while other examples in Figure 3 show endemic and relict distributions with considerable gaps in the geographical range suggesting extinctions of many local populations.

More than 100 distribution maps of birds which regularly inhabit high-altitude woodlands have been overlain to produce various summary maps, of which three examples are shown in Figure 4. The total species richness (Figure $4 \mathrm{~A}$ ) amounts to more than 40 of these species per grid unit in some of the cordilleras and along the edges between the Andean slopes and high plateaus in Peru. If opportunistic visitors to the Polylepis zone in the páramos of the northern Andes (e.g. several mid-altitude hummingbirds, spinetails and tanagers) had been 

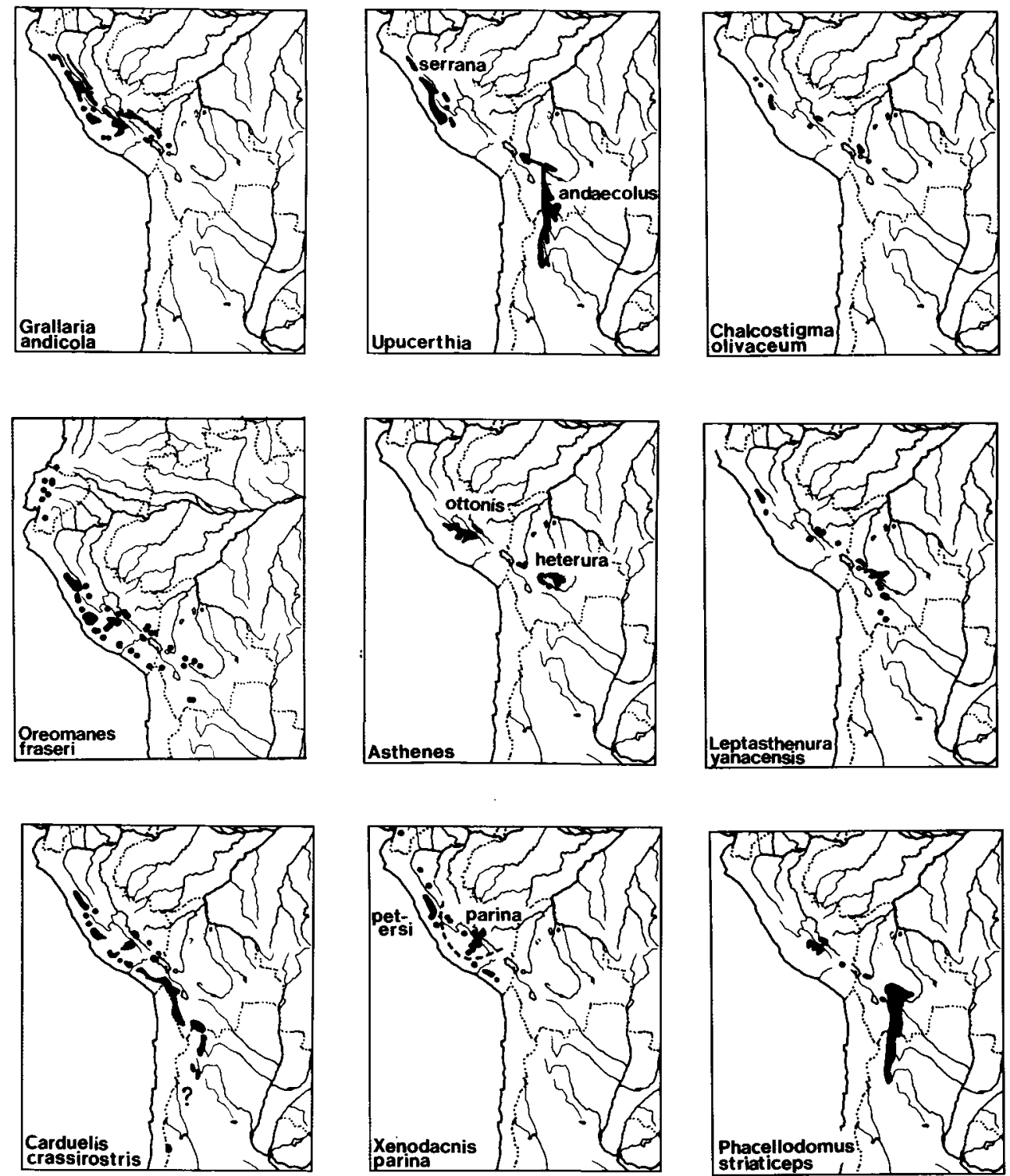

Figure 3. Examples of distributions of birds inhabiting Polylepis woodlands. Left column shows patchy distributions of three specialists, from the top Stripe-headed Antpitta, Giant Conebill and Thick-billed Siskin. The central column shows three pairs of endemic allospecies, from the top Striated and Rock Earthcreepers, Rusty-fronted and Maquis Canasteros Asthenes ottonis and heterura and Tit-like Dacnis (two megasubspecies). The right column shows species with disjunct distributions, from the top Olivaceous Thornbill, Tawny Tit-spinetail and Streak-fronted Thornbird. 


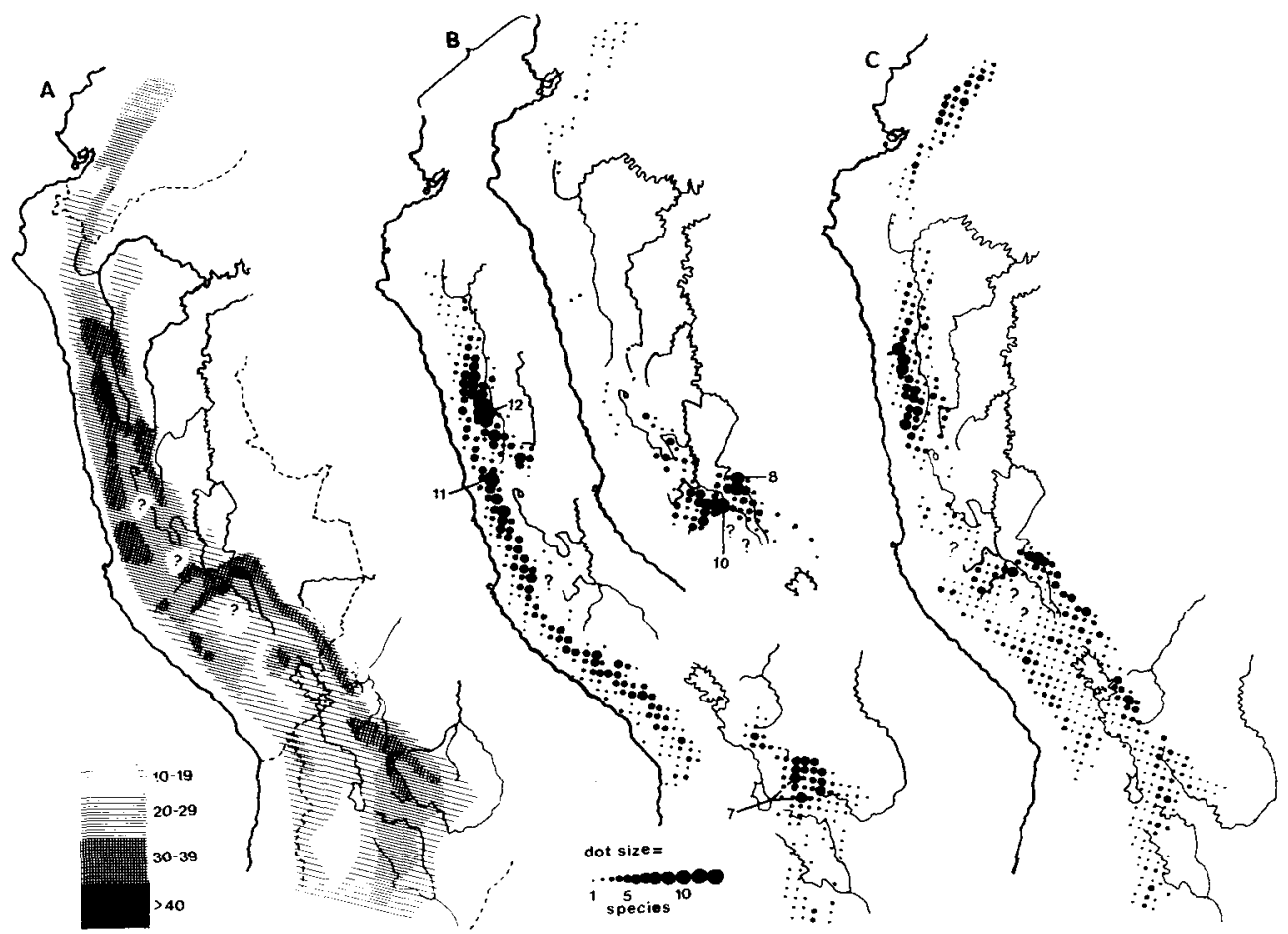

Figure 4. Density distribution (calculated for $25 \times 25 \mathrm{~km}$ grid) of birds which inhabit Polylepis woodlands fairly regularly at least in part of their range (A), of species and megasubspecies endemic to a smaller area (B, which please note contains two maps) and those disjunctly distributed (C). Species strongly adapted to Polylepis are marked with ${ }^{*}{ }^{* *}$ for the most specialized forms).

The taxa pooled in B are: $(1$, along the western Cordillera of Peru, EBA B27 of ICBP 1992) Metallura phoebe, Colaptes atricollis, Upucerthia serrana*, Leptasthenura striata* and pile$a^{* *}$, Cranioleuca baroni, Asthenes pudibunda, Scytalopus (magellanicus) affinis*, Zaratornis stresemanni*, Mecocerculus leucophyrys pallidior*, Anairetes nigrocristatus* and reguloides, Conirostrum tamarugense ${ }^{*}$, Atlapetes nationi, seebohmi and $r$. rufigenis*, Incaspiza personata, Poospiza alticola ${ }^{* *}$ and rubecula; (2, the South-east Peruvian Andes, EBA B31; the inset map) Nothoprocta taczanowskii, Aglaeactis castelnaudii*, Oreonympha nobilis, Cinclodes (excelsior) aricomae $^{* *}$, Leptasthenura xenothorax ${ }^{* *}$, Cranioleuca albicapilla, Asthenes ottonis and virgata, unnamed forms of Scytalopus, Xenodacnis p. parina*, Atlapetes rufigenis forbesi and Poospiza caesar; (3, The Bolivian Andes, EBA B35) Oreotrochilus adela, Upucerthia andaecola*, Asthenes heterura, Diglossa carbonaria, Saltator rufiventris, Atlapetes fulviceps, Poospiza boliviana and

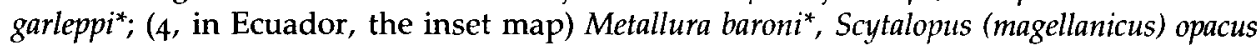
and Chalcostigma herrani. The species pooled in C are: Oreotrochilus estella, Lesbia victoriae and nuna, Chalcostigma olivaceum ${ }^{*}$ and stanleyi ${ }^{*}$, Leptasthenura yanacensis ${ }^{* *}$ and andaecola*, Phacellodomus striaticeps, Asthenes dorbignyi superspecies, A. flammulata and urubambense*, Anairetes alpinus ${ }^{* *}$ and Xenodacnis (parina) petersi (including bella)*

included, a similar density of species in fact prevails also in these parts (see Parker et al. 1985 for an area in extreme northern Peru).

Species with restricted ranges cluster together in certain areas of endemism (Figure ${ }_{4} \mathrm{~B}$ ). Conspicuous aggregations of limited-range species are found in 
western Andes of Peru (density peaks in the northern part of the Lima department and in Cordillera Blanca), in the south-east Peruvian Andes (density peak in Apurimac, in the Runtacocha highlands south-west of the town of Abancay) and in the Bolivian Andes (density peak in the Cochabamba Basin, mainly on the northern and western mountain scarps). These density peaks are close to places with peak densities for endemic birds of the lower temperate and subtropical zones. The areas of endemism correspond to the Endemic Bird Areas (EBAs) B27, B31 and B35 of ICBP (1992). However, Figure 4 B demonstrates that the density of endemism permits a more precise identification of "hot-spots" than the simple outline of EBAs demonstrated by ICBP. Between these areas the woodlands of the paramos and those of the altiplanos are inhabited only by intruding species of the adjacent habitats or by widespread and adaptable species. Hardly any records of limited-range species exist for the extensive Polylepis zones in the northern part of the Titicaca Basin and in western Bolivia. This indicates that these zones have communities composed of widespread species.

For species which are disjunctly distributed with a weak differentiation of the populations indicating a fairly recent (Holocene?) range fragmentation (Figures 3 [right] and ${ }_{4} \mathrm{C}$ ), the distribution gaps are mainly between Ecuador and Peru and between Cordillera Blanca (and adjacent mountains in Huánuco and Pasco) and the south-east Peruvian Andes (see Olivaceous Thornbill Chalcostigma olivaceum and Tawny Tit-spinetail Leptasthenura yanacensis in Figure 3). The central Peruvian gap is in an area where the highlands are interrupted by several deep, arid gorges (Figure $1 \mathrm{C}$ ) and with a moderate cloud-cover even over the eastern ridges. These ridges may have a particularly low capacity for maintaining populations of birds adapted to fairly humid high-altitude habitat. The distribution of the Streak-fronted Thornbird Phacellodomus striaticeps (Figure 3) indicates dispersal from the thornscrub of the Bolivian valleys to rainshadow pockets in central Peru, with a relict population left in the large Polylepis tracts north-west of Lake Titicaca.

\section{Effects of habitat fragmentation}

The Polylepis woodlands have, in general, considerably higher densities of bird species than the surrounding open land. The diversity peaks in rather humid highlands with several not too widely spaced patches of Polylepis woodland. Within such areas (first line in Table 1 ), individual woodland patches of only 2-5 ha often have as many as $30-45$ bird species. Gorges with a semi-continuous strip of shrubbery connecting high- and mid-altitude woodlands (not included in Table 1) may have even more species (above $3,500 \mathrm{~m}$ ). A high diversity was also found in certain areas with "fallow-shifting" (alternate periods of agriculture and fallow), provided that groups of trees and bushes are left in a mosaic pattern.

Among the large woodlands (second line in Table 1), some are rich in species, but those isolated far inside the puna, most of them semi-arid and bushy, rarely have more than 25 species. This corresponds to the values found in small isolated patches (third line in Table 1). However, some of the sedentary birds of the Polylepis woodlands (e.g. Stripe-headed Antpitta and Giant Conebill) show a remarkable ability to maintain their presence in small, isolated habitat islands. 
Table 1. Number of bird species in 101 well studied sites above $3,500 \mathrm{~m}$ (each defined as observations done within less than one square kilometre area with scrub, bushes or trees present)

\begin{tabular}{lcccccccc}
\hline Habitat & \multicolumn{7}{c}{ Number of species } \\
\cline { 2 - 8 } & $0-9$ & $10-14$ & $15-19$ & $20-24$ & $25-29$ & $30-34$ & $35-39$ & $40+$ \\
\hline $\begin{array}{l}\text { Small Polylepis patches in } \\
\text { districts with numerous } \\
\text { patches }\end{array}$ & 1 & 8 & 8 & 6 & 6 & 5 & 1 \\
$\begin{array}{l}\text { Large isolated Polylepis } \\
\text { woodland }\end{array}$ & 1 & 3 & 2 & 3 & 3 & 2 & 2 & 2 \\
$\begin{array}{l}\text { Small }\left(<1 \mathrm{~km}^{2} \text { ) isolated }\right. \\
\text { woodland }\end{array}$ & 2 & 2 & 1 & & & & \\
$\begin{array}{l}\text { Terrain with occasional } \\
\text { bushes or trees of Polylepis }\end{array}$ & & 3 & 2 & 1 & 1 & & & \\
$\begin{array}{l}\text { Planted Polylepis hedges } \\
\text { Other bushy habitats }\end{array}$ & 3 & 11 & 5 & 2 & 4 & 3 & 1 & 1 \\
\hline
\end{tabular}

Apparently the number of specialists present is more a question of quality than of the size of the habitat island. Woodlands with few species often have low within-patch habitat diversity or they are arid, maybe an effect of the generally reduced vegetation cover. Another negative factor is encroachment by the adaptable and dispersive species that make up the bird community of the surrounding steppe. Polylepis stands planted near houses become "filled up" entirely by those birds that are generally present near houses (e.g. House Wren Troglodytes aedon and many emberizids), and lack specialists.

The birds that appear to be most vulnerable to isolation and habitat fragmentation are frugivores, scansorial furnariids and specialized hummingbirds (species with straight bills, whether short or long, whereas those with slightly curved bills, such as hillstars Oreotrochilus spp., are unaffected by the insularity of the woodland habitat).

\section{Discussion}

Vicariance (speciation caused by natural range fragmentation) of sister species and possible speciation scenarios

The biogeographic analysis (Fjeldså 1992), based on three-taxon statements, permits correlation of distributions of sister taxa and their "outgroup". These tests demonstrate the following scenarios:

1. Many birds of the humid cis-Andean zone (i.e. eastern slope) of Peru speciated and became specialized to the Polylepis zone after trans-Andean dispersal and later isolation in western Peru or sometimes with a further isolation of populations in Cordillera Blanca and the Pacific slope.

2. Birds of the thornscrub and deciduous woodlands of southern Brazil and the chaco of Bolivia and northern Argentina became adapted to highland conditions during entrapment in the Cochabamba basin. Following dispersal across 
the altiplano, other populations became isolated in Apurímac, in the Cordillera Blanca or on the adjacent Pacific slope in Lima.

3. The pattern here resembles (2) but apparently with dispersal from the Pacific slope rather than from the south.

4. Past alternations occurred between opportunities for dispersal across central Peru and isolation of populations in the Cordillera Blanca and the south-east Peruvian Andes.

Disruptive selection across altitudinal ecotones (in parapatric situations) or fragmentation into many small local populations (Vuilleumier 1984) did not lead to speciation and strong specialization. Instead, this happened in strictly allopatric situations, when populations were isolated in Polylepis-dominated woodlands far away from possible founding areas (Fjeldså 1992). Vicariance patterns 1-4 are followed by groups of closely related populations as well as by very well-marked species, suggesting several time dimensions for dispersal and vicariance. This fits well into the paradigm of repeated Pleistocene cycles of expansions and contractions of forest habitat (Figure 5).

In the cold/arid periods of the Pleistocene, most of the highlands were covered by ice. However, the local climate may have been favourable immediately adja-

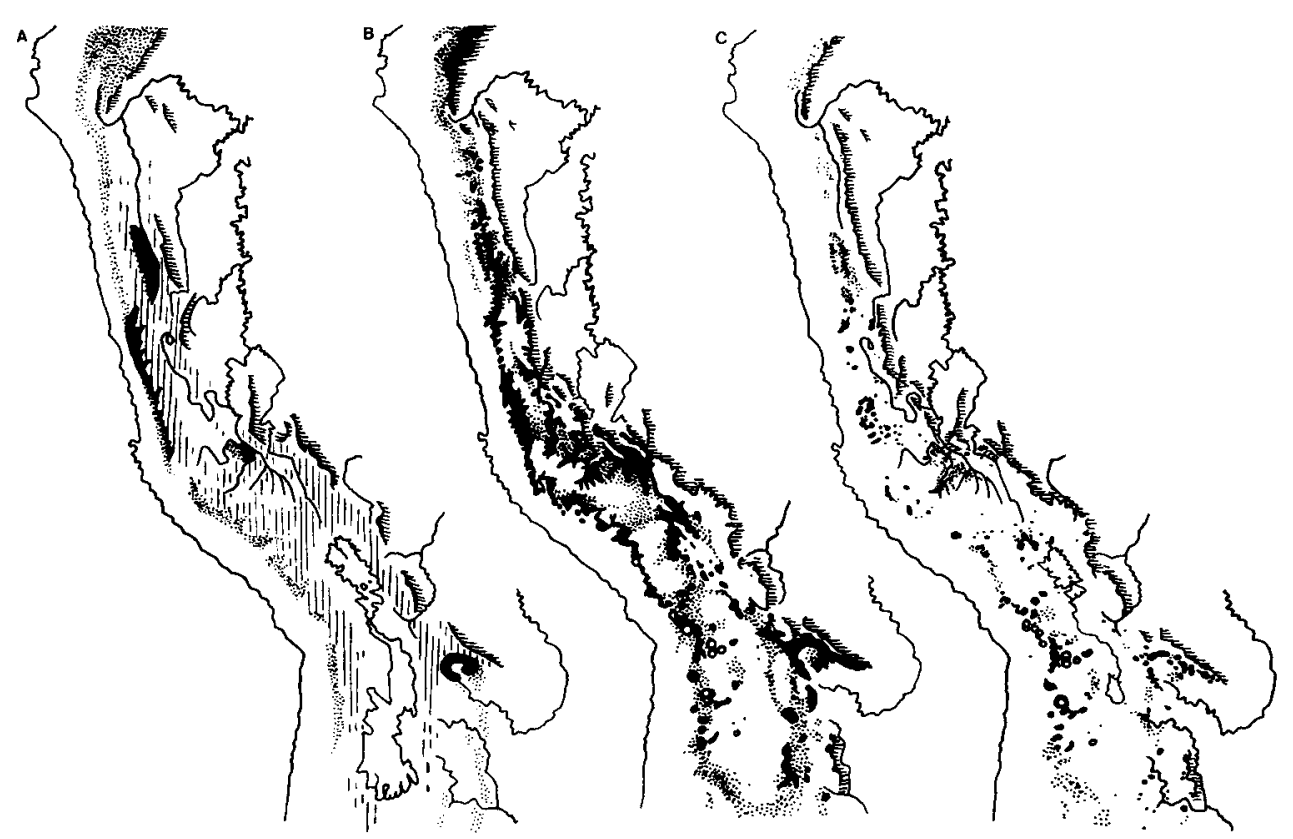

Figure 5. Assumed distribution of high-altitude woodlands, (A) during a cold/arid Pleistocene cycle based on areas of endemism of birds and topographic patterns), (B) during a warm/humid episode, maximum extension judged from ecological amplitudes of Polylepis species and a few palynological studies), and (C) the present distribution. Black, mountain tracts densely dotted with Polylepis woodlands; stippled, occasional Polylepis thickets; dense shading, humid treeline habitat, with Polylepis admixed especially during the Pleistocene; vertical shading, ice-caps. 
cent to the glaciers (see Lindroth 1965). Periglacial Polylepis zones may have been best developed on the most humid Andean slopes (see, e.g., Hansen $e t$ al. 1984, van der Hammen and Cleef 1986), but as their bird populations would be in gene-flow contact with those of adjacent cloud-forests, this did not lead to any specialization. This happened instead in semi-humid gorges that were isolated by ice-capped crests. The assumed location of such areas is shown in Figure 5A (see Fjeldså 1992: 46-47 for arguments about why these areas are likely to have maintained suitable climates).

\section{Implications of the biogeographic analysis for conservation}

Although many Polylepis-adapted birds have extremely small populations, no extinction has yet been documented. However, this might be an artifact of the late start of the exploration of most highland areas.

The existence of fairly consistent biogeographic patterns offers an indirect postulate of past extinctions. I assume that, if taxa usually differentiate by sequential entrapment in, e.g., three areas during the Pleistocene $(A \rightarrow B \rightarrow C)$, then a disjunction (A C) signals that one population (B) is gone (it is unfortunately impossible to say whether absence of the terminal population[s] represent extinction or lack of colonization). Based on this rationale, and using distribution data for ten clades of species inhabiting montane valley systems from Bolivia to northern Peru, I postulate that two species (between Rock Earthcreeper Upucerthia andaecola and Striated Earthcreeper $U$. serrana [Figure 3], and between Plain-tailed and Rufous-sided Warbling-finches Poospiza hypochondria) have gone extinct.

Also large gaps within "tracks" combining sister taxa can be seen as evidence of an extinction of local populations (as between Rufous-fronted Parakeet Bolborhynchus ferrugineifrons [Colombia]) and Andean Parakeet B. orbygnesius [Peru/Bolivia], Stout-billed Cinclodes Cinclodes excelsior [Colombia/Ecuador] and Royal Cinclodes [south-east Peruvian Andes]) and distinctive species (between Bearded Helmetcrest Oxypogon guerinii [northern páramos] and Bearded Mountaineer Oreonympha nobilis [south-east Peruvian Andes]).

Many parts of the high Andes are rich in species of woodland birds (Figure $4 \mathrm{~A})$, but the endemic and disjunct (relict) species cluster together in certain parts of the species-rich areas (Figure $4 \mathrm{~B}$ and $\mathrm{C}$ ). It follows that much of the regional species richness is made up mainly of wide-ranging (adaptable or dispersive) species, which are well equipped to survive habitat fragmentation and conversion.

Because of the complementarity of the EBAs, the complex critical faunal analyses (stepwise or as network) (Ackery and Vane-Wright 1984, Margules et al. 1988) appear rather superfluous, at least with respect to species with limitf 1 ranges. However, in order to judge the efficiency of basing the conservation priorities on complementary centres of endemism (rather than on total species richness) I analysed combinations of bird lists from 31 well-studied areas (Table 2). Each of these had been studied for $2-7$ days with visits to several habitats above $3,500 \mathrm{~m}$, at least one of these being woodland, and all sites contained within a $10 \times 10 \mathrm{~km}$ area. (These areas are not fully representative for the 
Table 2. The total number of landbird species for sets of three study areas situated $>500 \mathrm{~km}$ apart in the highlands of Peru and Bolivia

\begin{tabular}{lccc}
\hline Kind of sample & $\begin{array}{c}\% \text { of total regional } \\
\text { fauna }\end{array}$ & $\%$ of endemics & $\begin{array}{c}\% \text { of threatened } \\
\text { and near-threatened }\end{array}$ \\
\hline One site of three centres of endemism & 59 & 54.5 & 66.7 \\
Sample for species-rich areas $(n=105)$ & $48.9 \pm 6.2$ & $35.1 \pm 10.7$ & $19.3 \pm 11.3$ \\
Total sample of regional fauna $(n=495)$ & $44.1 \pm 9.6$ & $30.4 \pm 11.3$ & $13.7 \pm 12$ \\
\hline
\end{tabular}

The values are expressed as percentage of the 210 species well established above 3,500 $\mathrm{m}$ within the highlands of Peru and Bolivia, 55 of these being endemic to a small area (those listed in the legend to Figure 4, plus endemics inhabiting open terrain) and 15 being threatened or near-threatened (Collar et al. 1992). The top line shows three sites representing the three peaks of endemism in Figure ${ }_{4} \mathrm{~B}$ (on the east slope of Cordillera Blanca, south-east of Abancay in Apurímac and on the western scarp of the Cochabamba Basin). The second line gives mean values and standard deviations for all 105 datasets for species-rich areas $(>30$ species in Figure $4 \mathrm{~A})$. The bottom row gives, as a sample of the regional fauna, mean values for all 495 combinations of study sites. (The values differ somewhat from those published in Fjeldså [1991b] because of a redefinition of the species considered for inclusion and use of a larger dataset.)

Each study area comprised several habitats, including woodland, situated within a $10 \times 10 \mathrm{~km}$ area, and studied for 2-7 days. The species lists used for this calculation are deposited at the Zoological Museum, University of Copenhagen.

regional fauna, as most were in the more "interesting" highlands - thus five in Cordiliera Blanca, six in the Apurímac/Cuzco area.)

The first line in Table 2 shows the composition of the pooled faunas of three study areas right in the centres of endemism in the western Peruvian Andes, south-east Peruvian Andes and the Bolivian Andes. This is based on the bird lists from areas comprising (1) Quebradas Carhuascanchas, Rurichinchay and Rurec near the town of Huantar in Cordillera Blanca, (2) the puna and adjacent valley near Runtacocha immediately south-east of the town of Abancay in Apurímac, and (3) Cerro Kheñwa Sandra on the scarp fringing the Cochabamba Basin to the west. It is remarkable that as many as $10(66.7 \%)$ of the threatened and near-threatened birds of the Peruvian-Bolivian high-altitude zone were recorded in these three plots. Nearly equally high values would also be obtained by using data from Quebrada Pucavado and the Yanac area in Cordillera Blanca, near Oyón in Lima, the Totora area in Cordillera Vilcabamba (Apurímac/Cuzco border), the Abra Málaga area or valleys above Urubamba in Cordillera Vilcanota (Cuzco) and Parque Nacional Tunari on the scarp immediately north of Cochabamba. The three centres are adjacent to valleys with several endemic birds (11 of these threatened or near-threatened) of scrub, deciduous woodland and cloud-forest patches in the lower temperate and subtropical zones. These centres are therefore extremely good as key areas for conserving the birds of the ICBP (1992) EBAs B27, 31 and 35.

The top line in Table 2 is compared with data from all study areas, where a comparable sampling was done by pooling the species lists for all 495 combinations of three study areas situated at least $500 \mathrm{~km}$ apart. In order to compare the relative values of centres of endemism and general richness of species as criteria for selecting conservation priorities I present a separate calculation based 
on those 105 datasets where all three sites were rich in species ( $>30$ species in Figure $4 \mathrm{~A}$ ).

The differences in these columns in Table 2 confirm, beyond my expectation, that centres of endemism are better conservation priorities than areas selected on the basis of total species richness. The standard deviations show that the variation in number of threatened species is highly skewed, and evidently the identification of centres of evolution of new species was efficient for finding areas with particular concentrations of threatened species.

Comparison with the more fragmentary biogeographic data for insects (collected on the 1987 expedition: see Povolny 1990 for description of part of this material) indicates that the site selection based on avian endemism is relevant for biodiversity conservation in a wider sense (but see Major 1988 and Gentry 1992 for the multitude of unrelated, very local speciation events in plants).

Why are centres of endemism suited as conservation targets?

As pointed out first by Terborgh and Winter (1983), centres of endemism are important because of the potentially favourable cost-effectiveness of reserves in these areas. Most threatened and near-threatened birds of the high Andes (Collar et al. 1992) are "endemic", with very small ranges, but four of them are widespread or show a relict (disjunct) distribution. All four such species (Kalinowski's Tinamou Nothoprocta kalinowskii, Tawny Tit-spinetail, Ashbreasted Tit-tyrant and White-tailed Shrike-tyrant) have been recorded near the assumed species-gathering centres. This suggests a more general tendency, that the same areas serve the differentiation of new species as well as the survival of relict populations of older species. I find it worthwhile to examine the possible biological causes why threatened species cluster together in this way, and why identification of centres of speciation are such good priorities for conservation. The following discussion is speculative but concordant with current ideas about factors that influence species richness and life strategies of species.

The prevailing explanation of the high diversity of species around the equator used to be stability permitting dense packing of ecological niches (MacArthur 1969). However, this view failed to explain the actual geographical patterns of diversity, as local opportunities for vicariance events not only add to the regional species richness but also lead to enrichment of within-habitat diversity (Ricklefs 1989). However, a high species richness can also be caused by "patch dynamics", creating strong temporal or spatial habitat heterogeneity. This is the case in some man-modified landscapes which have habitat mosaics and numerous but mainly widespread and adaptable species, including some with opportunistic habits and high breeding potentials. Similar processes appear also to account for accumulation, over long geological periods, of large numbers of species in the central Amazon lowlands and in swampy savannas (Fjeldså 1993). It follows from this that the numbers of species per se (and probably also the taxic dispersal: see Williams et al. 1991) may sometimes be quite misleading as criteria for where to invest the resources available for preventing extinctions.

Areas of endemism may differ from areas where high species richness is maintained by temporal and spatial heterogeneity in some fundamental ways. 
Although the role of Pleistocene forest refuges in creating patterns of endemism may have been overemphasized, this model appears to have a high explanatory power where ecological gradients and climatic cycles may interact within areas with a distinctive geological structure (Fjeldså 1993). It is implicit in this model that new species evolved where a certain ecological regime could be maintained (often in a small, peripheral habitat pocket) during a major climatic cycle. Thus, a centre of endemism not only represents a place which maintained woodland habitat while surrounding areas periodically became barren; it may be more appropriate to see it as a centre of stability. The individual species that constitute an endemic fauna are not necessarily adapted to occupy different niches in the same macrohabitat. In fact, most EBAs have species with quite diverging habitat requirements (see Cracraft 1985, although I do not accept his interpretations of this). The Cochabamba basin has, besides species mentioned in the legend to Figure ${ }_{4} \mathrm{~B}$, some open-land endemics and some endemics inhabiting subtropical deciduous woodland. With its complex topography of humidity-capturing ridges and valleys, this area may have had a habitat mosaic contained within a climatically fairly stable area, at a time when adjacent areas were being ravaged by periods of severe drought or cold. The populations of once-widespread species entrapped in such areas would not only differentiate and become separate species, but their life-history traits would also be adjusted to the predictability of their territory (and to the high risk of dispersal into the more rigorous or unpredictable surroundings). I would expect them to become long-lived birds which were prudent breeders and reluctant to leave their core habitat. Such adaptations would explain why endemic species are often sensitive to habitat changes and apparently unsuited to disperse and compete with the regional biota outside the "refuge". However, such speculations should be critically tested, and there is also a great need to study the possible implications for the resilience of endemic and non-endemic communities.

We cannot predict the effects of the global climatic change on protected areas. However, if I am right in assuming that the centres of endemism illustrated in Figure ${ }_{4} \mathrm{~B}$ represent centres of climatic predictability during the climatic cycles of the past, then I believe that these areas will be good choices also for the future.

\section{Approaches for protecting species}

Although woodland habitats should be protected anywhere in the high Andes, we must foresee that large portions will disappear long before sustainable landuse can be widely implemented. This is unlikely to happen without new ways of economic planning which take environmental costs into account, and without property rights that give those who use the environment responsible for managing it. In the mean time, actions to conserve biodiversity must be concentrated on more specific goals. Considering the daunting rate of destruction of the remnants of virgin habitats, there is little to be gained in taking special action for single species, and much more by using resources for habitat conservation in places with large aggregations of vulnerable species. Table 2 demonstrates how small are the areas actually needed to include the majority of threatened Andean birds. 
For the preservation of endemics, the location of reserves will probably be more critical than their size (Terborgh and Winter 1983, Gentry 1992). Species with small ranges are usually small, and show moderate to high densities where they occur. Many Polylepis-adapted birds appear to manage to survive as extremely small local populations. However, the protection of such relict patches involves a strong sample of the fauna as a whole. The communities inhabiting isolated habitat patches are likely to change gradually because of pressure from the adaptable species in the converted adjacent habitats. Species which must wander in search of resources (frugivores and nectarivores) have special difficulties in strongly fragmented habitats, and it will certainly be advantageous to maintain habitat mosaics and fairly continuous strips of habitat connecting mid- and high-altitude woodlands. To maintain the genetic variation I propose that this kind of habitat protection is done in two or three adjacent mountain tracts within each centre of endemism.

The project areas could be: (1) for the west Peruvian Andes the Pueblo Quichas area near Oyón and Cordillera Blanca (mountains above Yanac and in the Pucavado, Rurec, Rurichinchay and Tutapác gorges); (2) for the south-east Peruvian Andes the Runtacocha highland south of the Apurimac Canyon, the Totora area in Cordillera Vilcabamba and Cordillera Vilcanota; (3) for the Bolivian Andes Cerro Tunari north of the Cochabamba Basin and the scarp west of the basin from Cerro Kheñwa Sandra southwards to the Oruro border.

Within these areas it is essential to permit regeneration of the vegetation by eliminating the effects of trampling and grazing by cattle and above all the burning of grassland. Whatever the origin of the burning was, today it must be considered a tradition without any or with only very inferior practical purposes (Laegaard 1992).

The important Runtacocha highland (project area 2) has some 40 Polylepis patches, most of these of 1-4 ha, but one patch covers 80 ha. As the two families living nearest to this patch have adequate firewood supplies in some tiny woodlands near their huts, and thus hardly use the large woodland at all, this could be strictly protected and reserved for research into virgin woodland ecology. However, campaigns to protect the remaining Polylepis patches in this puna, and its birds, will hardly succeed unless habitat degradation is also countered by the creation of considerable "buffer zones" for afforestation, and more intensive land-use in certain parts.

The Runtacocha woodlands lack formal protection today, since the Bosque Ampay Sanctuario only $10 \mathrm{~km}$ further to the north-west has good woodland habitat only at $3,000-3,900 \mathrm{~m}$. On the other hand, large parts of Cordillera Blanca (Project area 1) are formally protected (Huascaran Biosphere Reserve), and some Polylepis woodland exists within the Parque Nacional Tunari (Project area 3).

Formal protection (top-down approach) is no guarantee, however. Peru has a rather detailed environmental and conservation legislation, but because of enormous social and cultural contrasts, such regulations are unlikely to win respect in the local campesino communities. Although stricter enforcement of the regulations would certainly have some effect, it may be more important to support land-use improvements and undertake educational campaigns aimed 
at reducing burning and at increasing an appreciation of ecosystem services, especially the value of woodland for protecting water and soil resources. Information campaigns may use the local radios (which most people listen to), and awareness courses for rural schoolteachers may also be effective. Above all, however, the locals should be involved in projects which are immediately attractive. Free medicine may be used to create interest, and subsidies for afforestation are important. In specific sites where firewood-cutting represents an acute threat to a very valuable habitat, provision of paraffin may be effective. Good techniques and customary rules for regulating land-use at the community level are still remembered in local lore, and might be relatively easy to reintroduce. Techniques which significantly increase agricultural yields (to take pressure off other areas) comprise crop rotation systems, agroforestry with small fields sheltered by rows and patches of trees, terraces (including low-investment "lazybed" versions made by turning the top-soil in horizontal strips) and mosaics of raised fields and water channels (camellones) on well-watered plains. It will also be necessary to regulate the cattlehold in such ways that natural vegetation can regenerate in steep terrain, and it would also be valuable to encourage the use of camelids rather than sheep and cattle (favoured by current legislation).

Campaigns have already been initiated in the Runtacocha area and nearby Cordilleras Vilcabamba and Vilcanota (G. Engblom, T. Aucca C.), and the interest shown by the locals gives hope that improvements could now follow in these areas, so rich in endemic species.

\section{Acknowledgements}

My studies have been financed mainly by the Danish Natural Science Research Council (Grants J. nr. 11-2250, 11-4143, 11-5958, 11-7073 and 11-7829). For companionship and help during the data-gathering phase I am indebted to P. Arctander, T. Aucca C., V. Baptista V., E. Bering, D. Boertmann, J. Brandbyge, G. Dreyfus, K. Fahnoe, O. Karsholt, J. Krabbe, S. Maijer, T. Valqui $H$. and W. Vust, and in particular to Niels Krabbe. Valuable information about birds of high-altitude Andean woodlands has been obtained especially from G. Engblom, P. Hocking, M. Kessler, T. A. Parker, T. S. Schulenberg, L. Venero and B. P. Walker. C. Rahbek kindly commented on a manuscript draft.

\section{References}

Ackery, P. R. and Vane-Wright, R. I. (1984) Milkweed butterflies. London: British Museum, Natural History.

Ansión, I. (1986) El arbol y el bosque en la sociedad andina. Lima: Instituto Nacional Forestal y Fauna - FAO.

Collar, N. J., Gonzaga, L. P., Krabbe, N., Madroño Nieto, A., Naranjo, L. G., Parker, T. A. and Wege, D. C. (1992) Threatened birds of the Americas: the ICBP/ILCN Red Data Book. Cambridge, U.K.: International Council for Bird Preservation.

Cracraft, J. (1985) Historical biogeography and patterns of differentiation within the South American avifauna: areas of endemism. Pp. 49-84 in P. A. Buckley, M. S. Foster, E. S. Morton, R. S. Ridgely and F. G. Buckley, eds. Neotropical ornithology. Washington, D.C.: American Ornithologists' Union (Orn. Monogr. 36). 
Earls, J. (1991) Ecología y agronomía en los Andes. La Paz: Hisbol.

Ellenberg, H. (1958) Wald oder Steppe? Die Natürliche Pflanzendecke der Anden Perus. Umschau 1958: 645-681.

Fjeldså, J. (1987) Birds of relict forests in the high Andes of Peru and Bolizia. Copenhagen: Zoological Museum.

Fjeldså, J. (1988) Status of birds of the steppe habitats of the Andean zone and Patagonia. Pp. 81-95 in P. D. Goriup, ed. Ecology and conservation of grassland birds. Cambridge, U.K.: International Council for Bird Preservation (Techn. Publ. 7).

Fjeldså, J. (1991a) The activity of birds during snow-storms in high-level woodlands in Peru. Bull. Brit. Orn. Club 111: 4-11.

Fjeldså, J. (1991b) The conservation of biological diversity: using birds to set priorities. Pp. ${ }_{157-175}$ in J. Aa. Hansen, ed. Environmental concerns - an interdisciplinary exercise. London and New York: Elsevier.

Fjeldså, J. (1992) Biogeographic patterns and evolution of the avifauna of the relict highaltitude woodlands of the Andes. Steenstrupia 18: 9-62.

Fjeldså, J. (1993) A comparison of African and South American avifaunas using molecular clocks. Proc. VIII Pan-Afr. Orn. Congr.: 67-75.

Fjeldså, J. and Drabbe, N. (1990) Birds of the high Andes. Copenhagen: Zoological Museum, and Svendborg: Apollo Books.

Frimer, O. and Nielsen, S. M. (1989) The status of Polylepis forests and their avifauna in Cordillera Blanca, Peru. Copenhagen: Zoological Museum.

Gentry, A. (1992) Tropical forest biodiversity: distribution patterns and their conservation significance. Oikos 63: 19-28.

van der Hammen, T. and Cleef, A. M. (1986) Development of the high Andean páramo flora and vegetation. Pp. 153-201 in F. Vuilleumier and M. Monasterio, eds. High altitude tropical biogeography. New York and Oxford: Oxford University Press.

Hansen, B. C. S., Wright, H. E. and Bradbury, J. P. (1984) Pollen studies in the Junín area, central Peruvian Andes. Geol. Soc. Amer. Bull. 95: 1454-1465.

ICBP (1992) Putting biodiversity on the map: priority areas for global conservation. Cambridge, U.K.: International Council for Bird Preservation.

Jordan, E. (1983) Die Verbreitung von Polylepis-Beständen in der Westkordillera Boliviens. Tuezenia 3: 101-112.

Krabbe, N. (1991) Avifauna of the temperate zone of the Ecuadorian Andes. Copenhagen: Zoological Museum technical report.

Lindroth, C. H. (1965) Skaftafell, Iceland - a living glacial refugium. Oikos (Suppl.): 1142.

Laegaard, S. (1992) Influence of fire in the grass páramo vegetation of Ecuador. Pp. 151170 in H. Balslev and J. L. Luteyn, eds. Paramo. London: Academic Press.

MacArthur, R. H. (1969) Patterns of communities in the tropics. Biol. J. Linn. Soc. 1: 1930.

Major, J. (1988) Refugia: a botanical perspective. Pp. 117-146 in A. A. Myers and P. S. Giller, eds. Analytical biogeography. London and New York: Chapman and Hall.

Margules, C. R., Nicholls, A. O. and Pressey, R. L. (1988) Selecting networks of reserves to maximize biological diversity. Biol. Conserv. 46: 63-76.

Parker, T. A., Schulenberg, T. S., Graves, G. R. and Braun, M. J. (1985) The avifauna of the Huancabamba region, northern Peru. Pp. 169-197 in P. A. Buckley, M. S. Foster, E. S. Morton, R. S. Ridgely and F. G. Buckley, eds. Neotropical ornithology. Washington, D.C.: American Ornithologists' Union (Orn. Monogr. 36).

Povolny, D. (1990) Gnorimoschemini of Peru and Bolivia (Lepidoptera, Gelechiidae). Steenstrupia 16: 153-223.

Ricklefs, R. E. (1989) Speciation and diversity: the integration of local and regional processes. Pp. 599-622 in D. Otte and J. A. Endler, eds. Speciation and its consequences. Sunderland, Mass.: Sinauer. 
Simpson, B. (1979) A revision of the genus Polylepis (Rosaceae: Sanguisorbeae). Smithsonian Contrib. Bot. 43: 1-62.

Terborgh, J. and Winter, B. (1983) A method for siting parks and reserves with special reference to Colombia and Ecuador. Biol. Conserv. 27: 45-58.

Vuilleumier, F. (1984) Patchy distribution and systematics of Oreomanes fraseri (Aves ?Coeribidae) of Andean Polylepis woodlands. Amer. Mus. Novit. 2777.

Vuilleumier, F. and Simberloff, D. (1982) Ecology versus history as determinants of patchy and insular distributions in high Andean birds. Evol. Biol. 12: 235-379.

Williams, P. H., Humphries, C. J. and Vane-Wright, R. I. (1991) Measuring biodiversity: taxonomic relatedness for conservation priorities. Austral. Syst. Bot. 4: 665-679.

Wing, E. (1986) Domestication of Andean mammals. Pp. 246-264 in F. Vuilleumier and M. Monasterio, eds. High altitude tropical biogeography. New York and Oxford: Oxford University Press.

JON FJELDS $\AA$

Zoological Museum, University of Copenhagen, Universitetsparken 15, DK-2100 Copenhagen, Denmark. 